Paedagogia Christiana

2/28 (201 I) - ISSN 1505-6872

Maciej Ostrowski*

Kraków

\title{
Przyroda jako miejsce spotkania z Bogiem
}

Temat podjęty w artykule jest kwestią szeroką. Staje się zatem rzeczą konieczną podejście wybiórcze. Naturalnie, na samym początku nasuwa się lektura znanych biblijnych tekstów, na które powołuje się teologia, gdy mówi o dowodach na istnienie Boga. Cały świat przyrody, jego doskonałość i piękno, są jedną z podstawowych dróg pozwalających na odkrycie istnienia Istoty, która stanęła u początku (Mdr 13, 1-9; Rz 1, 20). Z drugiej jednak strony, te same teksty mówią o ludzkiej głupocie, która nie pozwoliła „z dóbr widzialnych... poznać Tego, który jest" (Mdr 13, 1) i sprawiła, że chwała prawdziwego Boga została zamieniona na bałwochwalczy kult materialnych tworów. Wskazują zatem, iż sama obecność przyrody, choćby najpiękniejszej, nie poruszy ludzkiego serca. Wymagany jest ruch ze strony człowieka, jakiś wysiłek, który pozwoli mu odkryć i zinterpretować znaki Bożej obecności w naturze. Spotkanie Boga w przyrodzie, o którym chcemy traktować $\mathrm{w}$ artykule, ma charakter dynamiczny. Jest procesem, w który człowiek powinien aktywnie zaangażować się. Wyeksplikujmy zatem przynajmniej niektóre elementy świata przyrody, pozwalające człowiekowi na poznanie Boga i zbliżenie się do Niego ${ }^{1}$. Wskażmy na owe konieczne twórcze ruchy ze strony człowieka.

* Ks. prof. zw. dr hab. Maciej Ostrowski, prorektor Uniwersytetu Papieskiego Jana Pawła II w Krakowie, kierownik Katedry Teologii Pastoralnej Szczegółowej na Wydziale Teologicznym, duszpasterz turystów i pielgrzymów.

${ }^{1}$ Autor odsyła też do swojego artykułu: Rekreacyjne i estetyczne motywy ochrony przyrody, w: Mówić o ochronie przyrody. Zintegrowana wizja ochrony przyrody. Podręcznik dla 


\section{Piękno przyrody}

Katechizm stwierdza w prosty a zarazem dobitny sposób: „biorąc za punkt wyjścia ruch i stawanie się, przygodność, porządek i piękno świata, można poznać Boga" (KKK 32). Podczas pierwszej pielgrzymki do Polski bł. Jan Paweł II, wspominając swoje pobyty w uroczych okolicach Podhala, powiedział, iż człowiekowi potrzebne jest piękno. Dlatego ludzie ciągną w górskie okolice, ,by odnaleźć siebie w obcowaniu z przyrodą”" W W tym samym przemówieniu nawiązał do modlitewnych przeżyć, które zapewne były jego udziałem w malowniczo położonych miejscach. Dało się wyczuć, iż to właśnie kontekst piękna przyrody pozwolił Karolowi Wojtyle na zatopienie się w modlitewnej refleksji. Podobnych myśli doszukujemy się w wielu innych papieskich tekstach. Przytoczyć można choćby Tryptyk rzymski, w którym brzmią wyraźnie wspomnienia Wojtyły z jego wakacyjnych wędrówek wśród uroków lasów i górskich potoków. Podziw nad nimi pozwalał mu wejść w tajemnicę początków stworzenia i dojść do „Źródła” świata, którym jest Bóg ${ }^{3}$. Bliski kontakt z urokami natury przyczynia się do rozwoju człowieka i ubogaca ludzką osobę a zarazem wspiera w ukierunkowaniu na nadprzyrodzone wartości. Brak piękna powoduje stratę. Zaprzepaszczona zostaje jedna $\mathrm{z}$ ważkich szans.

Piękno określane jest w różnoraki sposób. Jego definicje tworzą filozofowie, teologowie, kulturoznawcy, architekci, artyści i wielu innych myślicieli. Każdy z ludzi w pewien sposób na własny użytek buduje tego rodzaju definicję. Piękno bowiem oprócz dających się ująć w słowa elementów obiektywnych posiada rys subiektywny. Powiedzmy dosadniej, jest ono doświadczane przez człowieka w sposób indywidualny, niejednokrotnie niepowtarzalny, a nawet nieprzekazywalny. Jest ono przeżywane, odczuwane osobiście i intymnie, budzi w człowieku całą gamę doznań, których bogactwo nie zawsze da się ująć w słowa. Każdy zatem odbiera piękno na swój niepowtarzalny sposób. Nie do końca da się opisać odczucia osoby podziwiającej panoramę gór bądź zachód słońca nad morzem.

\footnotetext{
studentów, Kraków 2002, s. 57-70. Obecny tekst jest w niektórych elementach rozwinięciem zawartych w nim myśli.

2 Jan Paweł II, Przemówienie w Nowym Targu, 8 czerwca 1979 r., w: Pielgrzymka Jana Pawła II do Polski. Przemówienia, dokumentacja. Tekst autoryzowany, Poznań-Warszawa 1979, s. 169.

3 „Zatoka lasu zstępuje w rytmie górskich potoków ten rytm objawia mi Ciebie [...] Jeśli chcesz znaleźć źródło, musisz iść do góry, pod prąd, Przedzieraj się, szukaj...”. Jan Paweł II, Tryptyk rzymski. Medytacje, Kraków 2003, s. 9, 11.
} 
Podejmijmy jednak próbę obiektywizacji definicji. Piękne jest coś, co się podoba, wzbudza w człowieku przeżycie estetyczne, sprawia swoistego rodzaju przyjemność. Posłużmy się refleksją wielkiego, choć nierzadko dziś krytykowanego myśliciela, św. Tomasza z Akwinu. Znany jest on z jasności, prostoty a zarazem trafności określeń. Św. Tomasz wskazuje na trzy warunki piękna przedmiotu: całość, czyli doskonałość (integritas sive perfectio), proporcję, czyli harmonię (proportio sive consonantia) oraz blask (claritas) ${ }^{4}$. Inni myśliciele wskazują też na wdzięk i majestatyczność.

\subsection{Doskonałość}

Gdy mówimy o całości i doskonałości, mamy na myśli przedmiot, któremu nic nie brakuje. Przyroda wyszła z rąk Bożych, stworzona według odwiecznego planu Kreatora. Każdy z jej bytów stanowi integralną całość. Czy to będzie pojedyncze drzewo, czy las, w którym jest nie tylko zbiór drzew, ale współżyją różne gatunki roślin i zwierząt, a nadto znajdują się twory przyrody nieożywionej. Wszystkie te elementy koegzystują ze sobą. Wzajemnie sobie służą i uzupełniają się.

Wśród ludzkich tworów znajdujemy wiele niedoróbek. Życie przynosi aż nadto przykładów źle zaprojektowanych budowli, których architektom zabrakło wyobraźni i nie przewidzieli wszystkich wymagań przyszłej eksploatacji. Wykonawcy nie potrafią wykonać poprawnie wszystkich elementów projektu albo są zwyczajnie niedbali. Stąd też zgryźliwa ale słuszna krytyka. Obserwacje dotyczące ludzkich działań bezwiednie przenosimy na świat przyrody. I wówczas budzi się niepokój, czy przyroda przetrwa suszę, upały, mrozy, huragan bądź inne katastrofy natury. Okazuje się, iż Stwórca przewidział wszystko. Przyroda sama się broni. Istoty w niej żyjące są w stanie same wyżywić się, chociaż słyszeliśmy tyle alarmów o przeludnieniu bądź zagęszczeniu istot egzystujących w przyrodzie. Nie brak im mechanizmów przetrwania. Okazuje się nawet, że natura sama pokonuje dewastacyjne wpływy człowieka (ekologiczne zagrożenia). Przyrody nie trzeba poprawiać, bo wszystko, co potrzebne, już w niej jest.

Księga Rodzaju mówi o Bogu, który po ukończeniu stworzenia świata zachwycił się jego pięknem i doskonałością: „A Bóg widział, że wszystko, co uczynił, było bardzo dobre. I tak upłynął wieczór i poranek - dzień szósty. $\mathrm{W}$ ten sposób zostały ukończone niebo i ziemia oraz wszystkie jej zastępy stworzeń" (Rdz 1, 31-2, 1). Autor Księgi Powtórzonego Prawa śpiewa z podziwem: „Głosić chcę imię Pana: uznajcie wielkość Boga naszego; On

\footnotetext{
${ }^{4}$ Summa Theologiae, I, q. 39, a. 8.
} 
Skała, dzieło Jego doskonałe" (Pwt 32, 3-4). Przed człowiekiem otwiera się ta sama możliwość podziwu doskonałości świata. W ten sposób poniekąd wchodzi on w poznanie Boga.

\subsection{Proporcja i harmonia, różnorodność i porządek}

Piękno danej rzeczy tworzy proporcja zawartych w niej składowych elementów. Na proporcję zaś składają się stosunki ilościowe i jakościowe tychże części, ułożone we wzajemnej harmonii. Tworzą one razem swój własny porządek. Dalej, pięknym jest to, co charakteryzuje się większą złożonością i wielością. To, co jest zbyt proste (w znaczeniu mało skomplikowane, nieróżnorodne), nie jest tak piękne, jak to, co złożone $\mathrm{z}$ wielu różnorodnych elementów. Piękniejszym jest przedmiot nacechowany większą rozmaitością w przeciwieństwie do monotonności. Piękno odbiera się bowiem między innymi poprzez kontrast między obserwowanymi przedmiotami. Mówiąc o wielości i różnorodności, myślimy o nich nie jak o czymś, co rozbija, ale o harmonijnej całości. O pewnym współbrzmieniu różniących się między sobą składowych elementów całości. Można tu użyć sformułowania: jedność w rozmaitości ${ }^{5}$.

Czytamy w Księdze Mądrości: „Tyś wszystko urządził według miary i liczby, i wagi” (11, 20). Psalm 104 mówi: „Jak liczne są dzieła Twoje, Panie! Ty wszystko mądrze uczyniłeś: ziemia jest pełna Twych stworzeń. Oto morze wielkie, długie i szerokie, a w nim jest bez liku żyjątek i zwierząt wielkich i małych" (24-25). Katechizm, komentując fragment Księgi mądrościowej, stwierdza: „Ponieważ Bóg stwarza w sposób mądry, stworzenie jest uporządkowane” (KKK 299). W innym zaś miejscu, zwracając uwagę na źródła piękna wszechświata, podkreśla, iż „Porządek i harmonia świata stworzonego wynikają z różnorodności bytów oraz związków, jakie istnieją między nimi”. Wszystko to budzi podziw człowieka (KKK 341). A ów podziw kieruje go ku Stwórcy.

Obserwator piękna wschodu słońca odbiera je na zasadzie kontrastu niedawnej ciemności nocy ze światłem poranka. Wypoczywający na wiosennej łące cieszy się różnorodnością odcieni młodej zieleni, gatunków roślin, kolorów kwiatów i kształtów ziół. Autor artykułu słyszał relację polskich robotników pracujących na Uralu. Poważnym problemem dla nich, prowadzącym nawet do psychicznego załamania, była monotonia tamtejszej pogody i widoków; nieustanna szarzyzna barw otoczenia przez znaczną część roku. Niejednego z nas męczy ponure, gęsto zabudowane miasto z monotonnymi

\footnotetext{
${ }^{5}$ Por. G. Dogiel, Metafizyka, Kraków 1992.
} 
kształtami architektonicznymi. Stąd chce on doświadczyć odmienności naturalnej przyrody.

Dodajmy, iż wskazana harmonia przejawia się nie tylko wewnątrz przyrody. Winna ujawniać się przede wszystkim w ludzkiej osobie, w jej relacji do Boga i do wszystkich otaczających ją stworzeń. W Katechizmie, w rozdziale mówiącym o stanie pierwotnej łaski, której doświadczał człowiek w raju, czytamy: „Promieniowanie tej łaski umacniało wszystkie wymiary życia człowieka. Dopóki człowiek pozostawał w zażyłości z Bogiem, nie miał ani umierać, ani cierpieć. Wewnętrzna harmonia osoby ludzkiej, harmonia między mężczyzną i kobietą, a wreszcie harmonia między pierwszą parą i całym stworzeniem konstytuowała stan nazywany "pierwotną sprawiedliwością»" (KKK 376). Wieloraka harmonia zachodząca w przyrodzie i w samym człowieku ma swe ostateczne źródło w łasce Bożej. Łaska zaś to stan przyjaźni z Bogiem. W kontekście naszych rozważań o pięknie można zatem wnioskować dalej: najgłębszym źródłem piękna jest Boża łaska dana człowiekowi. Za pośrednictwem człowieka promieniuje ona w pewien sposób na wszystkie stworzenia. Przyroda jest piękna, gdyż także w niej odbija się piękno Bożej łaski - miłości Boga, który stworzył wszystkie byty. Bóg nie chce, by stworzenie poszło na zatracenie, gdyż kocha je bezinteresownie. Wręcz przeciwnie, pragnie, by rozwijało się ono na Jego chwałę. Mówi o tym dobitnie ten sam Katechizm: „Chwałą Boga jest to, by realizowało się ukazywanie i udzielanie Jego dobroci, ze względu na które został stworzony świat..." (KKK 294).

\subsection{Blask}

Blask jest czymś, co bije w oczy, oślepia. W określonym znaczeniu stanowi on ujawnienie na zewnątrz doskonałości istniejącej w przedmiocie, w pewnym sensie wypromieniowanie formy piękna, uwidocznienie jej, tak że uderza ona w oczy, a w obserwatorze budzi podziw i zachwyt.

Wobec piękna nocy i błyszczących na sklepieniu ciał niebieskich staje jakby oniemiały Psalmista, któremu wyrywa się z ust pieśń: „O Panie nasz Panie, jak przedziwne jest Twe imię po całej ziemi. Tyś swój majestat wyniósł nad niebiosa [...] Gdy patrzę na niebo, dzieło Twych palców, księżyc i gwiazdy, któreś Ty utwierdził" (Ps 8, 2. 4). Eklezjastyk w zachwycie pisze: „Wspaniałość gwiazd jest pięknością nieba, błyszczącą ozdobą na wysokościach Pana. Na polecenie Świętego trzymają się Jego wyroku i nie nużą się odbywaniem swych straży. Patrz na tęczę i wychwalaj Tego, kto ją uczynił, nadzwyczaj piękna jest w swoim blasku: otacza niebo kręgiem wspaniałym, a napięły ją ręce Najwyższego" (Syr 43, 9-12). 
Święty Augustyn pisał: „Zapytaj piękno ziemi, morza, powietrza, które rozprzestrzenia się i rozprasza; zapytaj piękno nieba... zapytaj wszystko, co istnieje. Wszystko odpowie ci: Spójrz i zauważ, jakie to piękne. Piękno tego, co istnieje, jest jakby wyznaniem. Kto uczynił całe to piękno poddane zmianom, jeśli nie Piękny, nie podlegający żadnej zmianie?"”.

Inaczej wygląda przyroda w blasku słońca a inaczej wtedy, gdy dzień jest ponury, niebo pokryte chmurami, a widoczność ograniczona przez mgłę. Niezwykłe przeżycie stanowi wędrówka nocą, przy pełni księżyca, w siarczysty mróz, poprzez zaśnieżone pola. W każdej drobinie śniegu pobłyskują ogniki odbitego światła. W niebieskawym świetle tajemniczo lśnią mijane przedmioty. Mimo nocy doskonale widać drogę i można odróżnić wiele szczegółów otoczenia. Podobne zjawiska można zaobserwować po deszczu. W kroplach rosy odbijają się a niekiedy załamują w barwach tęczy słoneczne promienie. I wtedy wyglądają one jak drogocenne kamienie, z których zbudowane jest eschatologiczne miasto z Apokalipsy św. Jana Apostoła. Nie ma w nim świątyni, „bo jego świątynią jest Pan, Bóg wszechmogący oraz Baranek. Miastu nie trzeba słońca ni księżyca, by mu świeciły, bo chwała Boga je oświetliła, a jego lampą - Baranek" (Ap 21, 22-23).

\subsection{Wdzięk}

Piękno wyraża się we wdzięku. Wdzięk można opisać rozmaitymi terminami: delikatność, uroda, harmonijność ruchów, naturalność, gracja. Wywołuje on w obserwatorze subtelne uczucia. Ostatni z zacytowanych terminów «gracja» pochodzi z łacińskiego słowa gratia, które oznacza też łaskę, dar darmo dany. Wdzięk jest darem oczarowującym i zachwycającym obserwatora. Ma on w sobie siłę przyciągającą, skupiającą i kierującą człowieka ku zainteresowaniu wartością, która stanęła przed jego oczami.

Starotestamentalny Eklezjastyk, zapewne podziwiając widok pól, pisze: „Wdzięk i piękność pociągają oko, a bardziej niż jedno i drugie - świeża zieleń zasiewów" (Syr 40, 22). Prorok Izajasz zaś wyśpiewuje:

Niech się podniosą wszystkie doliny, a wszystkie góry i wzgórza obniżą; równiną niechaj się staną urwiska, a strome zbocza niziną gładką. Wtedy się chwała Pańska objawi... Głos się odzywa: Wołaj! - I rzekłem: Co mam wołać? Wszelkie ciało to jakby trawa, a cały wdzięk jego jest niby kwiat polny. Trawa usycha, więdnie kwiat, gdy na nie wiatr Pana powieje [...] Trawa usycha, więdnie kwiat, lecz słowo Boga naszego trwa na wieki (Iz 40, 4-8).

\footnotetext{
${ }^{6}$ Sermones, 241, 2, cyt. za KKK 32.
} 
Sam Pan Jezus powie do uczniów: „Przypatrzcie się liliom na polu... nawet Salomon w całym swoim przepychu nie był tak ubrany jak jedna z nich... Jeśli więc ziele na polu, które dziś jest, a jutro do pieca będzie wrzucone, Bóg tak przyodziewa..." (Mt 6, 28-30). Podziwianie wdzięku tworów powinno w naturalny sposób kierować uważnego obserwatora ku Stwórcy.

Kto z nas nie obserwował klucza ptaków zbierających się jesienią do odlotu. Podziwiamy precyzję stada, fantastyczne, zmieniające się błyskawicznie kształty. Wzrok turysty zatrzyma motyl szybujący ponad łąką. I to nie tylko ze względu na bajecznie kolorowe skrzydła, lecz także delikatność i wdzięk lotu. Częstym tematem artystów malarzy jest galop konia. Fascynuje kształt mięśni, bijąca z nich siła, harmonia galopu.

\subsection{Majestatyczność - wzniosłość}

Majestatyczność wskazuje na coś, co góruje nad nami, jest wzniosłe. Sugeruje doskonałość, która nas przewyższa. W ten sposób wywołuje u człowieka zdumienie, podziw, a zarazem szacunek i uznanie. Fascynując, pociąga człowieka wzwyż. Posuwanie się ku górze jest symbolem rozwoju, zaś rozwój stanowi o pięknie.

Liczne biblijne teksty każą nam medytować i podziwiać otaczający nas świat, w którym majestat otaczających nas tworów przyrody jest zarazem odzwierciedleniem piękna i wielkości Boga. „Jesteś pełen światła - potężniejszy niż góry odwieczne” (Ps 76, 5). „Przed Nim kroczą majestat i piękno, potęga i jasność w Jego przybytku. Oddajcie Panu, rodziny narodów, oddajcie Panu chwałę i [uznajcie] potęgę” (Ps 96, 6-7). „Bóg przychodzi z Temanu, Święty z góry Paran. Majestat Jego okrywa niebiosa, a ziemia pełna jest Jego chwały. Wspaniałość Jego podobna do światła, promienie z rąk Mu tryskają, w nich to ukryta moc Jego" (Ha 3, 3).

Jan Paweł II podczas jednego ze swych przemówień w dolinie Aosty, patrząc na ogrom najwyższych alpejskich szczytów, zwrócił uwagę na ich majestat i potęgę, „które wywołują podziw, a zarazem zwracają myśl ku Bogu, który jest potężniejszy"7. W innym przemówieniu w tej samej okolicy wskazał, iż wyniosłość górskich szczytów przypomina nam wszystkim powołanie do świętości ${ }^{8}$. Świętość człowieka jest „,wznoszeniem się w górę” ku Bożej doskonałości, odzwierciedlaniem w sobie Bożego piękna. W tym

7 Jan Paweł II, Przemówienie w Courmayeur, 7 września 1986 r., w: Der Apostolische Stuhl. Ansprachen, Predigten und Botschaften des Papstes, Vollständige Dokumentation, Köln 1986, s. 667.

8 Tenże, Przyroda głosi chwałę Boga, homilia na Mszy św. w Cogne, 21 sierpnia 1994 r., „L'Osservatore Romano”, 9-10 (1994), s.17-18. 
miejscu kojarzy się natychmiast inna jeszcze bliższa nam papieska wypowiedź u stóp Tatr: „Dzisiaj dziękowałem Bogu za to, że wasi przodkowie na Giewoncie wznieśli krzyż. Ten krzyż patrzy na całą Polskę, od Tatr aż do Bałtyku, ten krzyż mówi całej Polsce: Sursum corda! - W górę serca!"’9.

Turystów zachęca do wędrówki pragnienie bezpośredniego obcowania $\mathrm{z}$ majestatem gór. $\mathrm{W}$ równej mierze fascynują one, jak i budzą strach oraz respekt. Tak jak o Bogu, mutatis mutandis, można o nich powiedzieć mysterium tremendum i mysterium fascinosum. $Z$ górskich szczytów inaczej widać ziemię, szersze są horyzonty. $Z$ perspektywy Boga, jego ewangelii, człowiek inaczej patrzy na świat. Inaczej ocenia zjawiska w nim się dziejące, niejednokrotnie przetasowuje hierarchię wartości. Wznoszenie się w górę wymaga wielkiego wysiłku i samozaparcia, ale jest zarazem wielką pracą nad sobą, w której człowiek realizuje powołanie do wyżyn świętości dane mu przez Boga.

Skonkludujmy tę część naszych analiz. Przyroda zawiera w sobie bogactwo piękna, wyrażone w różnych jej elementach. Piękno ma siłę pociągania ku czemuś - ku wyższym wartościom. Pociąga turystę, który doświadczył osobistego obcowania z przyrodą: odwiedził zakątki górskie, przewędrował przez malownicze łąki. Gdy pozostaje w swym domu, chciałby znów wrócić do otwartych przestrzeni natury i ponownie doświadczyć tych samych wrażeń. Piękno przyrody, w którym człowiek odkrył Boga, pociąga nie tylko do powtórzenia tych samych przeżyć, ale pociąga ku Temu, który stanął u początku wszystkiego.

Zwróćmy uwagę na inne jeszcze elementy świata natury, które mogą prowadzić człowieka bliżej Boga. Naturalnie i w nich zawiera się inny rodzaj piękna.

\section{Tajemnica życia}

Św. Paweł pisze w jednym ze swoich listów o Chrystusie: „Wszystko przez Niego zostało stworzone, byty widzialne i niewidzialne... On jest przed wszystkim i wszystko w Nim ma istnienie" (Kol 1, 16-17). A Jan Paweł II w swej encyklice Ewangelia życia, komentując tajemnicę życia człowieka i całej otaczającej go przyrody, napisze: „Wysławiać Ewangelię życia znaczy oddawać cześć Bogu życia-Bogu, który daje życie. Musimy wysławiać życie wieczne, od którego pochodzi wszelkie inne życie... To jemu zawdzięczają dusze swoją niezniszczalność, podobnie jak dzięki niemu żyją wszystkie

9 Tenże, Homilia w Zakopanem, 6 czerwca 1997 r., „L'Osservatore Romano”, Numer specjalny 31 maja-10 czerwca 1997 r., s. 67. 
zwierzęta i rośliny, w których echo życia jest słabsze. Ludziom, jako istotom złożonym z ducha i materii, Życie udziela życia" (nr 84) ${ }^{10}$. Trzeba zatem powiedzieć, iż wnikliwa kontemplacja tworów żywej przyrody prowadzi do poznania Boga, źródła wszystkich bytów. Życie przyrody jest odblaskiem Tego, który jedyny JEST i żyje.

Przebywający pośród przyrody obcuje blisko z tajemnicą życia. Miasto nosi w sobie pewną sztuczność, by nie powiedzieć martwotę. Nawet piękne rośliny hodowane w doniczkach nie są tym samym, co rosnące na otwartych polach. Czymś innym jest obserwacja przyrody na filmie, przeźroczach a nawet zza szyby pojazdu. Prawdziwy turysta chce dotknąć przyrody, postawić stopę na skale, wśród barwnych łąk. Można w tym momencie sparafrazować słowa św. Jana: „To wam oznajmiamy, co było od początku, cośmy usłyszeli o Słowie życia, co ujrzeliśmy własnymi oczami, na co patrzyliśmy i czego dotykały nasze ręce - bo życie objawiło się. Myśmy je widzieli, o nim świadczymy..." (1 J 1, 1-2). Dotyk ziemi, łączność z niebem i morzem, pozwala doświadczyć tajemnicy życia, a zarazem budzi szczególnego rodzaju solidarność ze światem stworzonym. Człowiek czuje się cząstką świata stworzeń. Obcujący z przyrodą w naturalny sposób staje się obrońcą życia. Odkrywa je jako jeden z najcenniejszych Bożych darów. Owo doświadczenie skłania go do oddania czci żyjącemu Bogu.

W kontekście naszych analiz nie można nie wspomnieć choćby jednym zdaniem, iż daru życia wegetatywnego kontemplowanego w otaczającej nas przyrodzie nie można widzieć w oderwaniu od innych form życia. Do nich należy życie człowieka - istoty wolnej i rozumnej, stworzonej na obraz Boży. Ale człowiek nosi w sobie coś więcej niż tylko życie fizyczne. Otwiera się przed nim życie wieczne. O nim, jako źródle wszelkich form życia, mówił zacytowany przed chwilą papieski tekst.

\section{W ciszy mówi Bóg}

Znana jest historia spotkania proroka Eliasza z Bogiem. Wyszedł on na górę, by na osobności spotkać się z Panem. „...A oto Pan przechodził. Gwałtowna wichura rozwalająca góry i druzgocąca skały [szła] przed Panem; ale Pan nie był w wichurze. A po wichurze - trzęsienie ziemi: Pan nie był w trzęsieniu ziemi. Po trzęsieniu ziemi powstał ogień: Pan nie był w ogniu. A po tym ogniu - szmer łagodnego powiewu. Kiedy tylko Eliasz go usłyszał, zasłoniwszy twarz płaszczem, wyszedł i stanął przy wejściu do groty"

\footnotetext{
${ }^{10}$ Papież cytuje tu Pseudo Dionizego Areopagitę.
} 
(1 Krl 19, 11-13). Spotkanie z Bogiem nie dokonało się wśród huku żywiołów ale w ciszy wypełnionej jedynie łagodnym szmerem odgłosu przyrody.

Cisza pomaga w załagodzeniu napięć i uspokojeniu ludzkich nerwów. Tylko skoncentrowany wewnętrznie jest w stanie wniknąć w swoje własne wnętrze, ale też przekroczyć siebie i wyjść naprzeciw transcendencji. Tradycja chrześcijańskiej duchowości zawsze mówiła, iż dla owocnego spotkania z Bogiem konieczne są odpowiednie warunki zewnętrzne. Do nich należy między innymi cisza pomagająca uniknąć rozproszeń i skupić się na sprawach ducha.

Współczesna cywilizacja jest wyją̧tkowo przeniknięta szumem a wręcz zgiełkiem. Być może, iż jest to jedna z przyczyn niezdolności do modlitwy a w konsekwencji odchodzenia człowieka od Boga. Naturalna przyroda niesie z sobą niepowtarzalną szansę wejścia w ciszę. W jednym ze swoich wakacyjnych przemówień Jan Paweł II wypowiedział trafne słowa: „Kto chce naprawdę odnaleźć samego siebie, musi nauczyć się obcować z przyrodą, bo oczarowanie jej pięknem wprowadza bezpośrednio w ciszę kontemplacji” A zaraz potem, kontynuując kwestię kontemplacji, dodał: „Różnorodność stworzenia pozwala wytyczyć wiele fascynujących dróg, na których dusza wrażliwa i wierząca bez trudu odnajduje echo owego tajemniczego i najdoskonalszego piękna, którym jest sam Bóg, źródło istnienia wszelkiej rzeczywistości"11.

\section{Woń przyrody}

Pod koniec naszych analiz zwróćmy uwagę na drobny a nie zawsze zauważalny element, który również może stać się drogą do spotkania z Bogiem. Jest nim naturalny zapach przyrody. Wyjątkowa jest woń ziół, kwiatów, drzew, wody. Także ona budzi w człowieku radość i zadowolenie. Szlachetna woń w języku biblijnym ma symboliczne znaczenie. Kieruje ona ku szczęściu nieba. Woń kadzidła palonego w kościołach staje się znakiem eschatologicznego szczęścia zbawionych a zarazem ofiary składanej Bogu i Jego uwielbienia (por. Kpł 4, 31). Św. Paweł mówi o poznaniu Boga jako „wdzięcznej woni” (2 Kor 2, 14). Wonność niekiedy „przedstawia fizyczną obecność bytu w sposób subtelniejszy i przenikliwszy"12.

${ }^{11}$ Tenże, Troska o przyrodę, przemówienie podczas Anioł Pański w Santo Stefano di Cadore, 11 lipca 1993 r., „L'Osservatore Romano”, 10 (1993), s. 60.

${ }^{12}$ G. Becquet, Wonność, w: X. Leon-Dufour (red.), Stownik teologii biblijnej, Poznań 1990, s. 1072-1073. 
Cywilizacja coraz częściej odbiera człowiekowi możliwość doznań związanych z naturalnymi zapachami, a czasem wręcz zabija w nas umiejętność korzystania $z$ najpiękniejszych aromatów przyrody. A przecież jest to też jeden z Bożych darów zawartych w przyrodzie. Coraz mniej jest takich zakątków, gdzie nie dochodzą wyziewy cywilizacji. Technika w sztuczny sposób usiłuje odtwarzać zapachy w postaci środków czystości, kosmetyków itp. Mają one nie tylko higieniczne znaczenie, ale w pewnym sensie starają się uczynić ludzkie życie przyjemniejszym. Można jednak zapytać, czy nie jest rzeczą piękniejszą kontakt z naturalnymi zapachami przyrody, wśród których człowiek znajduje inspirację radości spotkania czegoś, a raczej Kogoś, kto jest ponad światem.

\section{Odkrywanie przyrody jako miejsca spotkania z Bogiem - zadanie wychowawcze}

To, co powiedzieliśmy dotąd, nie oznacza, iż człowiek spotka Boga w przyrodzie w automatyczny sposób. Wróćmy do kwestii piękna. Jak powiedzieliśmy, można je analizować od obiektywnej strony. Ale jest ono także przeżyciem subiektywnym. Każdy z nas w inny sposób wyobraża je sobie, każdy na inny sposób je odbiera i doświadcza. Rodzi się zatem pytanie: czy człowiek zawsze jest zdolny do odczucia i uznania piękna przyrody? Czy zatem jest $\mathrm{w}$ stanie skorzystać $\mathrm{z}$ daru natury? I konsekwentnie, czy owo doświadczenie doprowadzi go do bliższego spotkania z Bogiem?

Ocena piękna bądź brzydoty zależy od człowieka obserwującego i poznającego świat, od jego wykształcenia, osobistego estetycznego wyrobienia, wrażliwości bądź wyznawanych poglądów. Człowiek musi sam uczynić krok naprzeciw przyrodzie, by odkrywać w niej znaki obecności Boga. Jednakże, z drugiej strony, trzeba podjąć wychowanie człowieka, by był on zdolny to uczynić.

Wróćmy do analizowanej wcześniej myśli św. Tomasza. Mówi on, że dla odkrycia piękna potrzebne jest najpierw poznanie (videre) - a potem upodobanie (placere, komplacencja). Możemy zastosować te słowa mutatis mutandis do wszelkiego rodzaju odkrywania znaków obecności Boga w przyrodzie. Trzeba zatem najpierw zobaczyć, uważniej przyjrzeć się przyrodzie, by potem upodobać w niej; znaleźć wśród niej radość, przyjemność, zadowolenie. By owa obserwacja pobudziła człowieka do poszukiwania w naturze czegoś, co prowadzi ku transcendencji, konieczne staje się wychowanie człowieka do umiejętności zauważania walorów przyrody i zdolności ich odbioru. Tu zaś rodzi się potrzeba kształtowania choćby w minimalnym stopniu umiejętności kontemplacji. 
Jan Paweł II w cytowanej już encyklice Evangelium vitae, mówiąc o darze życia, zachęca, byśmy poznawali piękno i dar każdej jego formy:

W tym celu należy przede wszystkim pielęgnować w nas samych i w innych postawę kontemplacji. Rodzi się ona z wiary w Boga życia, który stworzył każdego człowieka i cudownie go ukształtował (por. Ps 139, 14). Jest to postawa tego, kto widzi życie w całej jego głębi, kto dostrzega jego bezinteresowność i piękno oraz przyjmuje je jako wezwanie do wolności i odpowiedzialności. Jest to postawa tego, kto nie próbuje zagarnąc dla siebie rzeczywistości, ale przyjmuje ją jako dar, odkrywając w każdej rzeczy odblask Stwórcy, a w każdej osobie Jego żywy obraz (por. Rdz 1, 27; Ps 8, 6) (n. 83).

Trudno o bardziej obrazowe a zarazem syntetyczne określenie, czym jest kontemplacja. W szczególności kontemplacja otaczającej nas przyrody. Kontemplacja wymaga zdolności zatrzymania się na obserwowanym przedmiocie. Swoistego wnikania w głębię przedmiotu, jego istotę, cechy, by dostrzec całe jego bogactwo. Wymaga ona odpowiedniego czasu, by obserwator zdołał zinterioryzować rozmaitość wrażeń wzrokowych, słuchowych bądź zapachowych. Z tym procesem z kolei wiąże się cierpliwość. Cierpliwe wpatrywanie się, by móc dostrzec głębię rzeczywistości. Potrzebne jest i umiejętne wyrabianie spostrzegawczości. Równocześnie konieczne staje się wewnętrzne wyciszenie i oderwanie od rozpraszających człowieka zewnętrznych bodźców. Tylko milczący jest w stanie usłyszeć w pełni głosy świata. Jawi się praktyczne pytanie, jak uczyć współczesnego człowieka tego rodzaju umiejętności. Jest on nierzadko nastawiony antykontemplatywnie. Obserwuje otoczenie powierzchownie. Nastawiony na wiele szybko zmieniających się przeżyć. Skłonny do szukania mocnych wrażeń, niezdolny do wyciszenia i skupienia, niecierpliwy. Nie mówiąc już o tym, że wcale nie jest chętny wyjść ku naturalnej przyrodzie, zanurzony w wirtualnym świecie Internetu, skupiony na swym telefonie komórkowym, zadowolony z ekranu swego komputera, dobrze czujący się w dusznym pubie bądź jazgotliwej dyskotece. Wychowany na reklamach i czołówkach programów telewizyjnych, które w większości nie odzwierciedlają tego, co rzeczywiste. Jest to z pewnością poważny wychowawczy problem, i to nie tylko dotyczący rozważanego przez nas tematu.

Kilka poniższych wskazań może wydać się pobożnymi, nie do zrealizowania życzeniami. Jednakże cierpliwy wychowawca nie powinien kapitulować na wstępie. Nie wystarczy teoretyczne przekonywanie. Nie wystarczy także korzystanie z zastępczych środków. Nawet najpiękniejszy film, przeźrocza, muzyczne nagranie nie zastąpią bezpośredniego kontaktu z przyrodą. Owszem, mogą one pobudzić wyobraźnię i rozbudzić poznawcze chęci. 
Trzeba dążyć do wyprowadzenia człowieka na łono natury, by w bezpośrednim kontakcie sam dotknął i przeżył jej walory, sam ich zakosztował. Trzeba objaśniać znaki w niej ukryte, różne elementy jej piękna, ale także pozostawić człowieka sam na sam z nią. Konieczna jest zachęta do skupienia, wyciszenia, koncentracji spojrzenia, słuchu, powonienia. Niekiedy pomocne może być zwrócenie uwagi na brzydotę, która zakradła się na skutek nieodpowiedzialnej ingerencji człowieka w naturę (wspomniana już wyżej zasada kontrastu $)^{13}$.

Wydaje się, iż współczesny człowiek zarażony praktycznym materializmem utracił zdolność patrzenia na przyrodę jako Boży dar. Ważne staje się kształtowanie spojrzenia na otaczający świat w sposób utylitarny, jako na przestrzeń poszukiwania korzyści, przede wszystkim materialnych. W to miejsce formowanie zdolności do spojrzenia kontemplatywnego, a można nawet powiedzieć mistycznego. W tym ostatnim nie chodzi bynajmniej o powrót do pogaństwa ubóstwiającego naturę. Jest to spojrzenie na przyrodę, jako przestrzeń misterium (tajemnicę) objawiającego się nam prawdziwego i jedynego Boga. Potrzebne są tu w myśl św. Pawła „światłe oczy serca”, pozwalające odkryć ogrom Bożej mocy i wielkości (Ef 1, 18-23).

Dodajmy, iż ważną rzeczą jest nauczenie człowieka umiejętności opisu estetycznych przeżyć. Ma to być najpierw umiejętność skierowana do samego siebie. Ja sam muszę być zdolny do zdefiniowania tego, co widzę, moich własnych uczuć rodzących się pod wpływem odkrywanych walorów przyrody. Z kolei powinienem nauczyć się dzielenia swymi przeżyciami z drugim człowiekiem. Trzeba niekiedy zwyczajnie poszerzać zakres swojego słownictwa, by umieć w adekwatny sposób wyrazić wobec innych to, co dzieje się w moim wnętrzu. Wzajemne dzielenie się, przekaz osobistych doznań, pozwala drugiej osobie na jeszcze wnikliwsze wniknięcie w otaczającą nas rzeczywistość, dostrzeżenie dotąd niezauważanych znaków ukrytych w przyrodzie (np. gamy kolorów, kształtów, dźwięków, zapachów).

Niezaprzeczalny walor w tym względzie posiadają modlitwy, nabożeństwa, Msze św. polowe, organizowane wśród otwartej przyrody. Autor artykułu sam może złożyć świadectwo skuteczności takiej formy wychowania.

${ }^{13}$ Ciekawe ćwiczenie w tym względzie wypracował Ruch Światło-Życie (oazowy). Podczas rekolekcji wakacyjnych małe grupy z animatorem odbywają tzw. „,wyprawy otwartych oczu". Ich zadaniem jest uczulanie na rozmaite elementy przyrody, poprzez które dostrzec można znaki Bożej obecności. Grupa omawia wspólnie swoje doświadczenia, a także czyni je przedmiotem modlitwy na łonie przyrody. Stosuje się w nich również ćwiczenie milczenia oraz koncentracji na wybranych elementach otaczającej natury. 
Artykuł z pewnością nie wyczerpał bogactwa tematyki. Można ufać, iż będzie on nie tylko inspiracją do dalszych teoretycznych analiz, ale wskaże pewne kierunki wychowawczych działań.

\section{Nature as a Place to Meet God (Summary)}

The author of the article draws the reader's attention to the components of the natural world, which let us discover the existence of God the Creator. Beauty is suggested to be the most important of these components. Beauty resides in the perfection of the object observed, its proportions and harmony, variety and order, glamour, grace, majesty and grandeur. Unfolding the mystery of life itself is also conducive to the recognition of God, especially in the silence of nature and being surrounded by the scents it exudes. However, the very contact with nature is not enough to encounter God. The author of the article contemplates the ways of educating people which may facilitate their discovery of God in nature. It is necessary to teach man how to contemplate the surrounding world. Careful observation, concentration on the object, calming down, leaving the hustle and bustle behind are indispensable to learn this, as well as the ability to describe your own feelings and the rejection of the utilitarian attitude to the world. The author makes reference to biblical texts, thoughts presented in papal speeches and private observations. 